\title{
Changes in lens proteins in undernourished and well-nourished patients with cataract
}

\author{
BY K. SEETHARAM BHAT \\ National Institute of Nutrition, Indian Council of Medical Research, Jamai Osmania, \\ Hyderabad-500 007, A P India
}

(Received 16 June 1981-Accepted 7 January 1982)

\begin{abstract}
1. Patients with cataract were classified into undernourished (twenty-eight subjects) and well-nourished (twenty-seven subjects) groups based on the anthropometric index, weight $(\mathrm{kg}) / \mathrm{height}(\mathrm{m})^{2}$. Those with a value for the index of less than 18 were considered as undernourished.

2. Lenses were classified into four groups on the basis of nuclear colour as proposed by Pirie (1968). Lenses of pale uniform colour or yellow colour were included in group 1, those with brownish-yellow nucleus in group 2 , those with a yellowish-brown nucleus in group 3 and those with brown nucleus in group 4 .

3. Irrespective of group, the wet weight, dry weight, percentage moisture and total protein content of cataractous lenses from undernourished patients were similar, as were the corresponding values for well-nourished patients. On the other hand, the percentage of soluble proteins in lenses tended to decrease with deepening of nuclear colour in both groups of patients. Further, soluble protein concentrations in lenses from undernourished patients were significantly lower as compared to those from well-nourished patients.

4. The results suggest that nutritional factors could influence the composition of cataractous lenses.
\end{abstract}

Cataract is a major cause of blindness all over the world and it is estimated that nearly sixteen million people are severely disabled by this eye disease (WHO, 1977). The factors leading to the formation of cataract are not clearly known. Apart from the normal ageing process, factors such as heredity, early senility, malnutrition and exposure to ultraviolet light have been implicated as acting either singly or synergistically in hastening the process of cataract formation (Kuck, 1970). A recent survey conducted by the Indian Council of Medical Research revealed that the incidence of cataract in the rural population is twice that of the urban population and that it occurred at a much earlier age among rural people (Indian Council of Medical Research, 1975). Studies on experimental animals have indicated a role for nutritional factors in the causation of cataract (McLaren \& Halasa, 1975). Extrapolation of this information to the human situation would however be hazardous in the absence of a precise knowledge of the molecular basis of human cataract formation. There have, however, been a few studies which have established a relationship between nutritional deficiency signs and cataract in humans. In an earlier report from this Institute biochemical evidence of riboflavin deficiency in a group of subjects with cataract was described (Bhat \& Gopalan, 1974) and this has been confirmed by other workers (Prchal et al. 1978). However, there is no evidence to suggest a relationship between the high incidence of cataract among the rural population and the widespread undernutrition.

Recent studies have shown a reduction in the proportion of water-soluble proteins in cataractous lenses (Scammon \& Hesdorffer, 1937; Dische \& Zelmenis, i959), suggesting that the aggregation of protein molecules could have been responsible for the loss of transparency in the lens. It is not known whether the nutritional status of an individual has any effect on the aggregating properties of lens proteins. The present study was, therefore, undertaken to obtain information on the changes in lens proteins in cataract patients of high and low socioeconomic status. 


\section{MATERIALS AND METHODS}

Subjects

A total of fifty-five patients with cataract was studied. They included twenty-nine male and twenty-six female patients between 40 and 80 years of age. Forty-four $(76.3 \%)$ of these patients were in the age-range 55-74 years; nine (16.4\%) were under the age of 54 years and four $(7.3 \%)$ were above the age of 75 years. Anthropometric measurements such as height, weight, mid-arm circumference and fat-fold thickness at triceps were recorded. Packed cell volume and haemoglobin (cyanmethaemoglobin method) determinations were made on finger-prick blood samples. Urine was tested for the presence of albumin and sugar.

\section{Lenses}

Cataractous lenses removed by cryoextraction at the Sarojini Devi Eye Hospital, Hyderabad, were deep-frozen. The lenses were transported to the Institute under solid carbon dioxide within 4-5 h after extraction. The lenses were either opaque or partially transparent. None of them was Morgagnian, hypermature or extracapsular. Lenses with opacity due to metabolic diseases and trauma were excluded from the study. The lenses were classified into four groups on the basis of nuclear colour as proposed by Pirie (1968). Lenses of pale uniform or yellow colour were included in group 1, those with brownish-yellow nucleus in group 2, those with a yellowish-brown nucleus in group 3 and those with brown nucleus in group 4.

\section{Analytical methods}

The dry weight of the lenses was determined by freeze-drying to constant weight. Each lens was then homogenized at $4^{\circ}$ in $2.5 \mathrm{ml} 0.02 \mathrm{M}$-sodium phosphate buffer $(\mathrm{pH} 7.4$ ) containing $0.1 \mathrm{M}$-sodium chloride and 0.025 M-EDTA (Giblin et al. 1978). The buffer was de-aerated with nitrogen and the homogenization was carried out rapidly allowing only a minimum amount of air to enter the solution. The homogenate was centrifuged at $9900 \mathrm{~g}$ for $15 \mathrm{~min}$ at $4^{\circ}$ in a Beckman ultracentrifuge (Spinco L50) using SW 5OL rotor to isolate the soluble proteins. The pellet was washed once with an equal volume of buffer and then resuspended in the buffer. Portions of the whole homogenates, opalescent supernatant fractions and pellet suspensions were analysed for protein by the method of Lowry et al. (1951).

\section{Statistical analysis}

The data were analysed by two $\times$ two-factor analysis of variance using Arc sine transformations. Student's $t$ test and multiple $t$ test were used, wherever feasible.

\section{RESULTS}

Patients whose anthropometric index, weight $(\mathrm{kg}) /$ height $(\mathrm{m})^{2}$, was less than 18 were considered undernourished (Rao et al. 1972).

Twenty-two of the twenty-seven undernourished patients and twenty of the twenty-eight well-nourished patients were in the age range $55-74$ years. The mean ( \pm SE) age of the patients in the former group was $61.4( \pm 1.54)$ years and of those in the latter group was $60 \cdot 1( \pm 1 \cdot 85)$ years.

All the urine samples examined were negative for sugar and albumin.

The anthropometric profile and packed cell volume and haemoglobin levels of patients with cataract are shown in Table 1 . The mean $( \pm S E)$ values for haemoglobin and packed cell volume and height were similar in the undernourished and well-nourished patients. On the other hand, the values for weight, arm circumference and fat-fold thickness were significantly lower in undernourished patients compared to well-nourished subjects. 
Table 1. Haemoglobin $(\mathrm{Hb})$, packed cell volume $(\mathrm{PCV})$ and anthropometric profile of patients with cataract

(Mean values with their standard errors; number of subjects in parentheses)

\begin{tabular}{|c|c|c|c|c|}
\hline & \multicolumn{2}{|c|}{ Undernourished } & \multicolumn{2}{|c|}{ Well-nourished } \\
\hline & Mean & $\mathbf{S E}$ & Mean & SE \\
\hline Age (years) & $61 \cdot 4$ & $1 \cdot 54(28)$ & $60 \cdot 1$ & $1.85(27)$ \\
\hline $\mathrm{Hb}(\mathrm{g} / \mathrm{l})$ & $133 \cdot 0$ & $4 \cdot 30(19)$ & $138 \cdot 0$ & $4 \cdot 40(22)$ \\
\hline $\mathrm{PCV}$ & 0.41 & $0.01(19)$ & 0.43 & $0.01(22)$ \\
\hline Weight (kg) & $38 \cdot 0$ & $1 \cdot 14(28)$ & $50 \cdot 9$ & $1.87(27)^{*}$ \\
\hline Height (m) & $1 \cdot 56$ & $0.02(28)$ & $1 \cdot 56$ & $0.02(27)$ \\
\hline Arm circumference (mm) & 2110 & $3.7 \quad(28)$ & $259 \cdot 0$ & $4.4(27)^{*}$ \\
\hline Fat fold thickness (mm) & $9 \cdot 5$ & $0.95(28)$ & $17 \cdot 5$ & $0.95(27)^{\star}$ \\
\hline
\end{tabular}

Table 2. Wet weight, dry weight, percentage dry weight and total protein content of cataractous lenses

(Mean values with their standard errors; number of lenses in parentheses)

\begin{tabular}{lcccc}
\hline \hline & \multicolumn{2}{c}{$\begin{array}{c}\text { Undernourished } \\
(28)\end{array}$} & & $\begin{array}{c}\text { Well-nourished } \\
(27)\end{array}$ \\
\cline { 2 - 5 } & Mean & SE & Mean & SE \\
\hline Wet wt (mg/lens) & 235.5 & 7.92 & 219.5 & 2.33 \\
Dry wt (mg/lens) & 56.1 & 1.76 & 54.9 & 1.13 \\
Percentage dry wt & 24.2 & 0.77 & 25.6 & 2.76 \\
Total proteins (mg/lens) & 56.1 & 1.77 & 55.3 & \\
\hline \hline
\end{tabular}

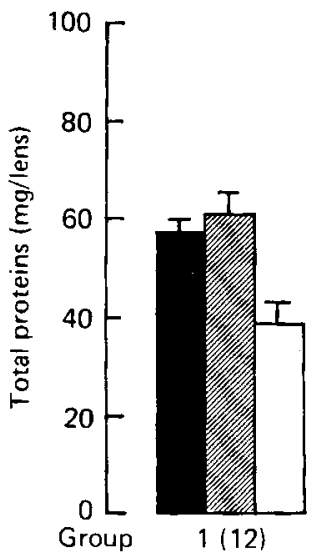

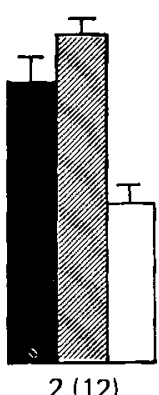

$2(12)$

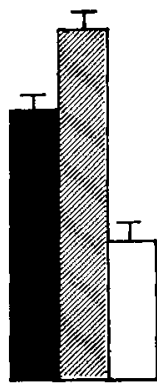

$3(16)$

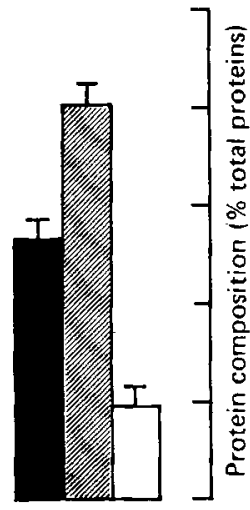

$4(15)$

Fig. 1. Total protein content and distribution of soluble and insoluble proteins in different groups of human cataractous lenses. ( $)$, total proteins $(\mathrm{mg} / \mathrm{lens}$, ordinate on left); ( insoluble proteins ( $\%$ of total, ordinate on right); $(\square)$, soluble proteins (\% of total, ordinate on right). Values are means with their standard errors represented by vertical bars; numbers of lenses analysed given in parentheses. For description of groups $1-4$ see p. 484 . 


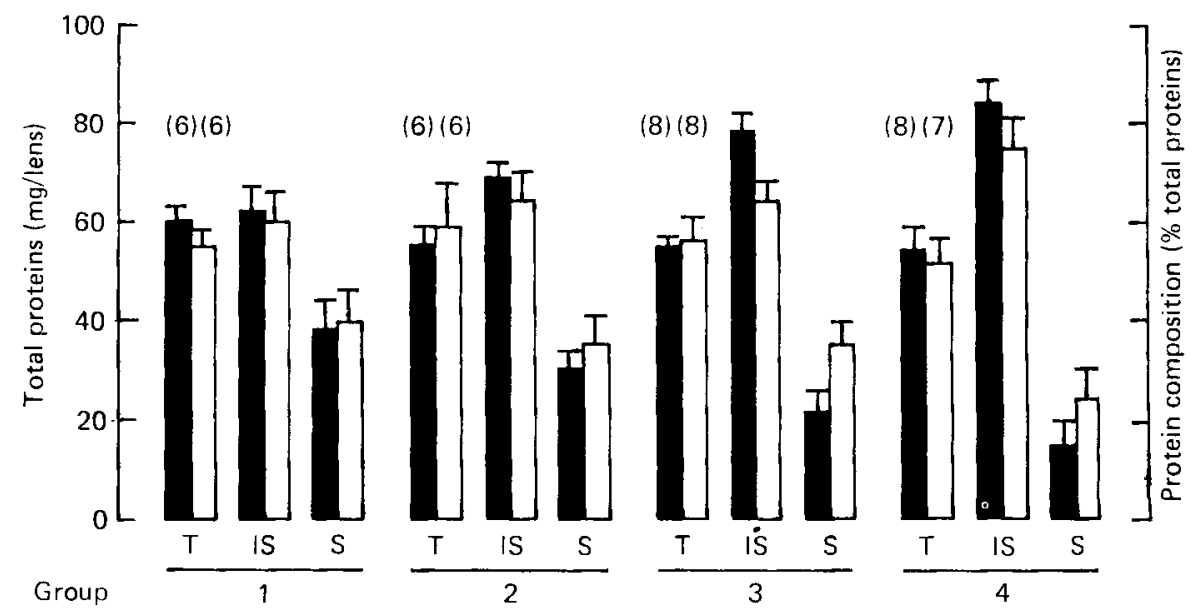

Fig. 2. Effect of nutritional status of patients on protein profile in different groups of cataractous lenses. (D), undernourished and ( $\square$ ), well-nourished. T, total proteins (mg/lens, ordinate on left); IS, insoluble proteins $(\%$ of total, ordinate on right); S, soluble proteins (\% of total, ordinate on right). Values are means with their standard errors represented by vertical bars; numbers of lenses analysed given in parentheses. For description of groups 1-4, see p. 484.

The mean ( $\pm \mathrm{SE}$ ) values for dry weight, wet weight and total protein content of the cataractous lenses are given in Table 2 . There were no significant differences between the two groups, in any of these factors.

The mean $( \pm \mathrm{SE})$ content of total lenticular proteins and the distribution of soluble and insoluble proteins (expressed as percentage of total protein) are presented in Fig. 1. A progressive increase in the percentage of insoluble proteins and a decrease in the percentage of soluble proteins were observed with deepening of nuclear colour. There were wide variations in the values for protein fractions within each group. Analysis of variance technique was used to see whether there exists any significant difference in the percentage of soluble protein among the four groups of lenses on one hand and between the two nutritional groups on the other hand. While in cataractous lenses from undernourished patients significant differences were observed for the percentage of soluble proteins among the different groups (groups 1 to 4) of lenses, no such marked differences were seen in well-nourished patients. Except in lenses of group 3, no significant differences were observed for the percentage of soluble proteins between the undernourished and well-nourished patients. However, the changes in lens protein fractions in the undernourished group of patients were of greater magnitude as compared to the well-nourished group (Fig. 2). When lenses belonging to patients less than 60 years of age were compared with those of patients more than 60 years of age, there were no significant differences in either undernourished or well-nourished patients.

\section{DISCUSSION}

The results presented in this paper suggest that the nutritional status, as judged by the anthropometric index, affects the distribution of soluble and insoluble protein fractions in cataractous lenses, especially those with a yellowish-brown nucleus (group 3). Neither age and sex of the individuals nor the nuclear colour of the cataractous lenses was found to influence the wet weight, dry weight, percentage moisture and total protein contents.

In a recent study, van Heyningen (1972a) compared cataractous lenses removed from patients in Oxford (England) with those from patients in Shikarpur (West Pakistan). A 
comparison of wet weight and dry weight determinations of these lenses with the present investigation shows that the extent of hydration of lenses in the present study is similar to type 3 and 4 clear lenses of Oxford and turbid lenses of Shikarpur. The turbid lenses of Oxford appear to be less hydrated compared to the lenses of the present study, while type 1 and 2 lenses of Oxford and Shikarpur clear lenses were more hydrated. It may be noted that in the present study, clear lenses were very few.

The observation that increase in insoluble proteins was related to increase in intensity of nuclear colour confirms earlier findings (Pirie, 1968; van Heyningen, 1972 b; Kramps et al. 1976; Truscott, 1977). It is not known to what extent the changes reported here differ from those of non-cataractous lenses, since no such lenses were analysed in our laboratory. Cataract and nutritional status appeared to be the major determinants of distribution of soluble and insoluble proteins in the present study. The differences observed in the protein fractions between undernourished and well-nourished groups could not have been due to ageing as the subjects in the two groups were age matched.

The aetiology and pathogenesis of the most frequent forms of lens opacity, i.e. the senile cataractous lenses, are still unknown. Rapid decrease in the solubility of proteins in the nuclear region has been suggested as a mechanism for cataract formation (Spector $e t$ al. 1973; Sigelman et al. 1974; Spector et al. 1974; Jedziniak et al. 1975). Since concentrations of total proteins were not altered, our results may be interpreted to indicate that part of the lenticular protein becomes insoluble during cataract formation. The greater magnitude of change seen in undernourished patients suggests that malnutrition may perhaps have a role in insolubilization of lens proteins. A number of nutritional factors have been implicated in cataract formation (McLaren, 1963; Chatterjee, 1973; Harding, 1980). However, the precise role of specific nutrients relating to this process remains to be determined. During the formation of nuclear cataract, lenticular protein has been shown to undergo conformational change and the possible causes have been discussed recently by Harding $(1972,1980)$. It may be suggested from our results that the nutritional status of the patients either singly or together with some of the previously-mentioned factors (Harding, 1980) may also alter the distribution of the protein fractions.

The author is grateful to Dr P. G. Tulpule, Director, National Institute of Nutrition and Dr S. G. Srikantia, former Director, National Institute of Nutrition, for their keen interest, valuable suggestions and continuous encouragement during the course of these studies. The author also wishes to thank the Superintendent and the staff of Sarojini Devi Eye Hospital, Hyderabad for their generous help in providing the cataractous lenses and is thankful to $\mathrm{Mr} \mathrm{T}$. Ramnath for assistance with statistical analysis. The skilful technical assistance of Miss Laxmi Rangashaye is greatly acknowledged.

\section{REFERENCES}

Bhat, K. S. \& Gopalan, C. (1974). Nutr. Metab. 17, 1.

Chatterjee, A. (1973). Ciba Fdn Symp no. 19, p. 265.

Dische, Z. \& Zelmenis, A. (1959). Am. J. Ophthal. 48, 500.

Giblin, F. J., Chakrapani, B. \& Reddy, V. N. (1978). Exp. Eye Res. 26, 507.

Harding, J. J. (1972). Biochem. J. 129, 97.

Harding, J. J. (1980). In Aging of the Lens [F. Regnault, O. Hockwin and Y. Courtois, editors]. Amsterdam: Elsevier.

Indian Council for Medical Research (1975). Bull. Indian med. Res. Counc. no. 5, p. 1.

Jedziniak, J. A., Kinoshita, J. H., Yates, E. M. \& Benedek, G. B. (1975). Exp. Eye Res. $20,367$.

Kramps, H. A., Hoenders, H. J. \& Wollensak, J. (1976). Biochem. biophys. Acta 434, 32.

Kuck, J. F. R. (1970). In Biochemistry of the Eye, p. 319 [C. N. Graymore, editor]. London: Academic Press.

Lowry, O. H., Rosebrough, N. J., Farr, A. L. \& Randall, R. J. (1951). J. biol. Chem. 193, 265.

McLaren, D. S. (1963). In Malnutrition and the Eye [D. S. McLaren, editor]. New York: Academic Press. 
McLaren, D. S. \& Halasa, A. (1975). In Cataract and Abnormalities of the Lens, p. 255 [J. G. Bellows, editor]. New York: Grune \& Stratton Inc.

Pirie, A. (1968). Invest. Ophthal. 7, 634.

Prchal, J. T., Conrad, M. E. \& Skalka, H. W. (1978). Lancet i, 12.

Rao, K. S. J., Mukherjee, N. R. \& Rao, K. V. (1972). Diabetes 21, 1192.

Scammon, R. E. \& Hesdorffer, M. B. (1937). Archs Ophthal. 17, 104.

Sigelman, J., Trokel, S. L. \& Spector, A. (1974). Archs Ophthal. 92, 437.

Spector, A., Li, S. \& Sigelman, J. (1974). Invest. Ophthal. 13, 795.

Spector, A., Stauffer, J. \& Sigelman, J. (1973). Ciba Fdn Symp. no. 19, p. 185.

Truscott, R. J. W. \& Augusteyn, R. C. (1977). Exp. Eye Res. 24, 159.

van Heyningen, R. (1972a). Exp. Eye Res. 13, 136.

van Heyningen, R. (1972b). Exp. Eye Res. 13, 148.

World Health Organisation (1977). WHO Chron. 31, 22. 